\title{
PENGARUH MODEL PEMBELAJARAN BERDASARKAN MASALAH PADA PEMBELAJARAN BIOLOGI TERHADAP HASIL BELAJAR DAN KETERAMPILAN BERPIKIR TINGKAT TINGGI DI SMA
}

\author{
Ria Mayasari ${ }^{1}$, Rabiatul Adawiyah ${ }^{1}$ \\ ${ }^{1}$ Program Studi Pendidikan Biologi, STKIP PGRI Banjarmasin \\ e-mail: riamayasari83@yahoo.com
}

\begin{abstract}
ABSTRAK
Penelitian ini bertujuan mengimplementasikan model pembelajaran berdasarkan masalah pada pembelajaran biologi terhadap hasil belajar dan keterampilan berpikir tingkat tinggi di SMA. Tujuan khusus penelitian ini adalah 1) Menguji signifikansi hasil belajar kognitif produk, 2) Menguji signifikansi keterampilan berpikir tingkat tinggi. Rancangan penelitian dalam penelitian ini adalah eksperimen semu. Menurut Populasi dari penelitian ini adalah seluruh siswa kelas X SMA Negeri di Kota Banjarbaru yang duduk di kelas X tahun pelajaran 2013/2014 dengan peminatan sains-matematika. Sampel penelitian ditetapkan dua kelas dari masing-masing sekolah, yaitu satu kelas SMA Negeri 1 Banjarbaru kelas perlakuan dan satu kelas SMA Negeri 2 Banjarbaru kelas kontrol. Teknik pengambilan sampel secara bertujuan (purpossive). Variabel bebas berkaitan dengan rumusan tujuan nomor satu dan dua adalah pembelajaran menggunakan model PBM. Variabel terikat adalah hasil belajar dan keterampilan berpikir tingkat tinggi. Variabel control dalam penelitian ini adalah kurikulum yang digunakan, latar belakang pendidikan guru, jumlah jam pelajaran, dan soal-soal tes. Teknik pengumpulan data dalam penelitian ini adalah 1) Hasil belajar siswa diperoleh melalui pre test dan post test. 2) Keterampilan berpikir tingkat tinggi diperoleh melalui pre test dan post tes. Instrumen penelitian sebelum digunakan disesuaikan dengan ketentuan yang berlaku pada kurikulum 2013. Hasil belajar kognitif produk dan kognitif proses diperoleh melalui pretest dan posttest dianalisis menggunakan.analisis kovarian (ANACOVA) yang dioperasikan menggunakan program SPSS versi 17 for windows. Hasil penelitian menunjukkan dengan menggunakan model Pembelajaran Berdasarkan Masalah berpengaruh positif terhadap hasil belajar siswa, ini dapat dilihat dari rata hasil belajar kelas kontrol 73,475 dan pada kelas perlakuan sebesar 82,917 dan dilihat dari nilai $F$ hitung $=4,157$ sedangkan $F$ tabel $=0,05$ artinya $F$ hitung $>F$ tabel. Sedangkan pada keterampilan berpikir tingkat tinggi siswa, ini dapat dilihat dari rata-rata nilai keterampilan berpikir tingkat tinggi kelas kontrol 65 dan kelas perlakuan 78,208 dan dilihat dari nilai $F$ hitung $=4,739$ sedangkan $F$ tabel $=0,05$ artinya $F$ hitung $>$ F tabel.
\end{abstract}

Kata Kunci: Berpikir Tingkat Tinggi, Hasil Belajar, Masalah, Pembelajaran

Pemberlakuan Kurikulum 2013 di sekolah menuntut adanya penggunaan model-model konstruktivistik. Salah satu model pembelajaran yang ditekankan penggunaannya dalam kegiatan pembelajaran adalah model pembelajaran berdasarkan proyek. Model ini di dalam implementasinya merupakan bagian dari model pembelajaran berdasarkan masalah.

Pembelajaran berbasis masalah (Problem-based learning) merupakan salah satu model pembelajaran inovatif yang memberi kondisi belajar aktif kepada siswa dalam kondisi dunia nyata (Yamin, 2012).
Pembelajaran berbasis masalah selanjutnya disingkat model PBM adalah salah satu pembelajaran yang didukung oleh teori konstruktivisme. Hal tersebut terkait dengan pembelajaran berbasis masalah yang mengarahkan siswa untuk memecahkan masalah disekitar lingkungan belajar siswa.

Penumpukan sampah merupakan salah satu masalah autentik yang masuk dalam pembelajaran di sekolah terkait konsep daur ulang sampah. Konsep ini adalah salah satu materi pembelajaran yang diajarkan di sekolah, bilamana diajarkan dengan menggunakan model PBM maka 
akan mengarahkan siswa-siswa untuk memecahkan masalah di sekitar lingkungan sekolah. Hal ini sesuai Permendikbud No 65 Tahun 2013 yang menghendaki pembelajaran efektif dan efesien sesuai dengan lingkungan sekolah masing-masing.

Konsep daur ulang sampah yang diajarkan dengan model PBM dapat memicu siswa untuk lebih aktif dalam proses pembelajaran. Mereka diharapkan dapat memukan cara-cara mendaur ulang sampah yang efektif dan efesien untuk kelestarian lingkungan. Penelitian pengembangan mengenai konsep daur ulang sampah sudah pernah diteliti terkait hasil belajar, kinerja, dan keterampilan berpikir tingkat tinggi siswa SMA pada pembelajaran konsep jenis dan daur ulang limbah melalui proses problem solving.

Penelitian mengenai konsep daur ulang sampah terkait dengan model pembelajaran pembalajaran berdasarkan masalah sudah pernah dilakukan (Yulinda, 2011; Ayatusa'adah, 2013). Mereka telah menghasilkan perangkat pembelajaran dan dalam penelitian ini berupaya untuk mengimplementasikan dalam konteks yang lebih luas. Hal ini menjadi alasan utama perlu dilaksanakannya penelitian tentang implementasi model pembelajaran berdasarkan masalah pada pembelajaran biologi terhadap hasil belajar dan keterampilan berpikir tingkat tinggi di SMA.

Penelitian ini bertujuan untuk mengimplementasikan model pembelajaran berdasarkan masalah pada pembelajaran biologi terhadap hasil belajar dan keterampilan berpikir tingkat tinggi di SMA. Tujuan khusus penelitian ini adalah menguji signifikansi hasil belajar siswa dan menguji signifikansi keterampilan berpikir tingkat tinggi siswa.

Hasil penelitian ini diharapkan bermanfaat bagi perorangan maupun institusi, yaitu 1) Bagi guru, penelitian ini dapat memberikan wawasan pengetahuan dalam menggunakan metode pembelajaran untuk pelaksanaan proses belajar mengajar terutama pembelajaran yang dilakukan menggunakan perangkat pembelajaran pada konsep daur ulang sampah terhadap hasil belajar dan keterampilan berpikir tingkat tinggi biologi di SMA. 2) Bagi siswa, penelitian ini diharapkan dapat meningkatkan kemampuan belajar selama proses pembelajaran dan melatih keterampilan berpikir tingkat tinggi. 3) Bagi sekolah, penelitian ini dapat memperoleh kesempatan mengembangkan ragam penelitian dan dapat memberikan kontribusi terhadap perbaikan dan mutu proses pembelajaran khususnya dalam mengimplementasikan Kurikulum 2013. 4) Bagi STKIP PGRI, penelitian ini sebagai bahan referensi dalam meningkatkan akreditasi perguruan tinggi.

Asumsi dalam penelitian ini adalah 1) Bahan ajar yang dikembangkan dapat diajarkan oleh guru maupun peneliti yang bersangkutan. 2) Bahan ajar yang dikembangkan dapat dipahami oleh siswa. 3) Waktu yang digunakan untuk pembelajaran ini sesuai dengan materi yang sedang dikembangkan. 4) Konteks materi yang dikembangkan sesuai dengan lingkungan belajar siswa.

Batasan masalah berkaitan dengan penelitian ini adalah 1) Perangkat yang digunakan pada kelas perlakuan adalah perangkat yang dikembangkan oleh peneliti sebelumnya (Ayatusa'adah, 2013). Perangkat ini disesuaikan dengan Kurikulum 2013. 2) Konsep biologi yang diajarkan dalam penelitian ini ialah konsep sistem daur ulang sampah pada siswa kelas XI SMAN dalam wilayah Kota Banjarbaru. Berkenaan dengan rumusan tujuan, dikemukakan hipotesis sebagai berikut:

$\mathrm{Ha}=$ Pembelajaran menggunakan model PBM berpengaruh positif terhadap hasil belajar siswa.

Ho = Pembelajaran menggunakan model PBM tidak berpengaruh positif terhadap hasil belajar siswa.

$\mathrm{Ha}=$ Pembelajaran menggunakan model PBM berpengaruh positif terhadap keterampilan tingkat tinggi siswa.

Ho = Pembelajaran menggunakan model PBM tidak berpengaruh positif 
terhadap keterampilan tingkat tinggi siswa.

\section{METODE PENELITIAN}

Rancangan penelitian dalam penelitian ini adalah Quasi Eksperimen eksperimen semu. Menurut Arikunto (2010) mengatakan bahwa disebut demikian karena eksperimen jenis ini belum mampu memenuhi persyaratan seperti cara eksperimen yang dapat dikatakan ilmiah mengikuti peraturan-peraturan tertentu. Desain penelitian yang digunakan adalah Non Equivalent Control Group Design.

\begin{tabular}{llr}
$\mathrm{O} 1$ & $\mathrm{X}$ & $\mathrm{O} 2$ \\
\hline $\mathrm{O} 1$ & & $\mathrm{O} 2$
\end{tabular}

Keterangan:

$$
\begin{array}{ll}
\text { O1 } & \text { Tes awal } \\
\text { O2 } & \text { Tes akhir } \\
\mathrm{X} & \text { Pembelajaran menggunakan model PBM } \\
---- & \text { Random assignment }
\end{array}
$$

Populasi dari penelitian ini adalah seluruh siswa kelas X SMA Negeri di Kota Banjarbaru yang duduk di kelas $\mathrm{X}$ tahun pelajaran 2013/2014 dengan peminatan sains-matematika. Sampel penelitian ditetapkan dua kelas dari masing-masing sekolah, yaitu kelas perlakuan pada SMAN 1 Banjarbaru dan kelas kontrol pada SMAN Banjarbaru. Teknik pengambilan sampel secara bertujuan (purpossive).

Variabel bebas berkaitan dengan rumusan tujuan nomor satu dan dua adalah pembelajaran menggunakan model PBM. Variaberl terikat adalah hasil belajar siswa. Variabel kontrol dalam penelitian ini adalah kurikulum yang digunakan, latar belakang pendidikan guru, jumlah jam pelajaran, dan soal-soal tes.

Teknik pengumpulan data dalam penelitian ini adalah 1) Hasil belajar siswa diperoleh melalui pre test dan post test. 2) Keterampilan berpikir tingkat tinggi diperoleh dari nilai pretest dan post tes. Instrumen penelitian yang digunakan dalam penelitian ini adalah instrumen hasil uji coba produk dari penelitian dan pengembangan (Ayatusa'adah, 2013). Instrumen penelitian sebelum digunakan disesuaikan dengan ketentuan yang berlaku pada Kurikulum 2013.

Hasil belajar siswa dan keterampilan tingkat tinggi diperoleh melalui pretest dan posttest dianalisis menggunakan analisis kovarian (ANACOVA) yang dioperasikan menggunakan SPSS for windows. Adapun penarikan kesimpulan signifikasi apabila nilai kemungkinan $\mathrm{H}_{0}$ ditolak lebih besar dari Pr, maka $\mathrm{H}_{0}$ diterima. Apabila kemungkinan $\mathrm{H}_{0}$ ditolak lebih kecil dari Pr, maka $\mathrm{H}_{0}$ ditolak. Keterampilan berpikir tingkat tinggi diperoleh nilai pretest dan posttes kemudian dianalisis deskriptif.

\section{HASIL DAN PEMBAHASAN}

\section{Hasil Belajar Siswa}

Data hasil belajar siswa diperoleh dari pre test dan post test. Skor pre test dan post test siswa kelas eksperimen dan kelas kontrol ditampilkan dalam Tabel 1.

Tabel 1. Deskripsi Statistik Hasil Belajar

\begin{tabular}{lccc}
\hline \multicolumn{1}{c}{ Kelas } & Mean & Std. Deviation & N \\
\hline Kontrol & 734.783 & 1.016 .174 & 23 \\
Perlakuan & 829.167 & 845.919 & 24 \\
Total & 782.979 & 1.038 .794 & 47 \\
\hline
\end{tabular}

Pada Tabel 1 ada peningkatan ratarata hasil belajar dari 73,475 pada kelas kontrol menjadi 82,917 pada kelas perlakuan. Kenaikan skor ini selanjutnya dilakukan uji Anakova menggunakan SPSS

\begin{tabular}{|c|c|c|c|c|c|}
\hline Source & $\begin{array}{c}\text { Type III } \\
\text { Sum of } \\
\text { Squares }\end{array}$ & Df & $\begin{array}{c}\text { Mean } \\
\text { Square }\end{array}$ & $\mathbf{F}$ & Sig. \\
\hline $\begin{array}{l}\text { Corrected } \\
\text { Model }\end{array}$ & $2446.808^{a}$ & 2 & 1.223 .404 & 21.386 & .000 \\
\hline Intercept & 883.850 & 1 & 883.850 & 15.451 & .000 \\
\hline PREHB & 1.400 .551 & 1 & 1.400 .551 & 24.483 & .000 \\
\hline KELAS & 237.791 & 1 & 237.791 & 4.157 & .048 \\
\hline Error & 2.517 .022 & 44 & 57.205 & & \\
\hline Total & 293.100 .000 & 47 & & & \\
\hline $\begin{array}{l}\text { Corrected } \\
\text { Total }\end{array}$ & 4.963 .830 & 46 & & & \\
\hline
\end{tabular}
for windows. Data uji Anakova hasil belajar disajikan pada Tabel 2.

Tabel 2. Ringkasan Hasil Uji Anakova Pengaruh 
Berdasarkan Tabel 2 tersebut diperoleh informasi bahwa nilai $\mathrm{F}$ hitung sebesar 4.157 dengan nilai 0.048 atau kurang dari 0.05, hal ini memberikan makna bahwa Pembelajaran Berdasarkan Masalah (PBM) berpengaruh terhadap hasil belajar siswa. Selanjutnya seperti yang dipaparkan pada Tabel 1 rata-rata hasil belajar juga menunjukkan bahwa rata-rata kelas yang menerapkan PBM lebih tinggi dari kelas kontrol.

Dari hasil penelitian menunjukkan bahwa pembelajaran biologi dengan menggunakan model Pembelajaran Berdasarkan Masalah (PBM) pada konsep Jenis Limbah dan Daur Ulang Limbah yang diterapkan di kelas eksperimen dapat meningkatkan hasil belajar siswa siswa secara signifikan. Ini dapat dilihat dari nilai pre test dan post test siswa setelah diberikan pembelajaran dengan model Pembelajaran Berdasarkan Masalah (PBM). Hal ini terbukti pada pengujian hipotesis dengan menggunakan program SPSS versi 17 for windows, dengan membandingkan nilai $t$ hitung dengan $t$ tabel, kemudian diperoleh nilai t hitung $>\mathrm{t}$ tabel.

Meningkatnya hasil belajar siswa menunjukkan bahwa pengetahuan dan ingatan siswa terhadap pembelajaran baik ini. Hal ini sesuai dengan Bloom dalam (Suprijono, 2010) yang menyatakan bahwa dominan kognitif adalah knowledge (pengetahuan dan ingatan), comprehension (pemahaman, menjelaskan, meringkas, dan contoh), application (menerapkan), analysis (menguraikan dan menentukan hubungan), synthetis (mengorganisasi, merencanakan, dan membentuk bangunan baru), dan evaluation (menilai). Hasil penelitian pembelajaran dengan menggunakan model pembelajaran berdasarkan masalah dapat meningkatkan hasil belajar produk dan peningkatan ini berpengaruh secara signifikan. Temuan ini sejalan dengan penelitian yang telah dilaporkan sebelumnya bahwa pembelajaran problem solving dapat meningkatkan hasil belajar siswa (Yulinda, 2011).

\section{Keterampilan Berpikir Tingkat Tinggi}

Data keterampilan berpikir tingkat tinggi siswa diperoleh dari pre test dan post test. Skor pre test dan post tes siswa kelas eksperimen dan kelas kontrol ditampilkan dalam Tabel 3.

Tabel 3. Deskripsi Statistik Keterampilan Berpikir Tingkat Tinggi

\begin{tabular}{lccc}
\hline \multicolumn{1}{c}{ Kelas } & Mean & Std. Deviation & N \\
\hline Kontrol & 650.000 & 1.400 .223 & 25 \\
Perlakuan & 782.083 & 1.204 .513 & 24 \\
Total & 714.694 & 1.456 .215 & 49 \\
\hline
\end{tabular}

Pada Tabel 3 ada peningkatan ratarata keterampilan berpikir tingkat tinggi dari 65,000 pada kelas kontrol menjadi 78,208 pada kelas perlakuan. Kenaikan skor ini selanjutnya dilakukan uji Anakova menggunakan program SPSS for windows. Data uji Anakova hasil belajar disajikan pada Tabel 4.

Tabel 4. Ringkasan Hasil Uji Anakova Pengaruh Berpikir Tingkat Tinggi

\begin{tabular}{lrrrrrr}
\hline Source & $\begin{array}{c}\text { Type III Sum } \\
\text { of Squares }\end{array}$ & df & $\begin{array}{c}\text { Mean } \\
\text { Square }\end{array}$ & F & Sig. \\
\hline Corrected & $3972.087^{\mathrm{a}}$ & 2 & 1.986 .044 & 14.719 & .000 \\
Model & 2.049 .708 & 1 & 2.049 .708 & 15.191 & .000 \\
Intercept & 1.835 .842 & 1 & 1.835 .842 & 13.606 & .001 \\
PREBK & 639.443 & 1 & 639.443 & 4.739 & .035 \\
KELAS & 6.206 .617 & 46 & 134.926 & & \\
Error & 260.464 .500 & 49 & & & & \\
Total & & & & & & \\
Corrected & 10.178 .704 & 48 & & & & \\
Total & & & & & & \\
\hline
\end{tabular}

Berdasarkan Tabel 4 Ringkasan Hasil Uji Anakova Pengaruh Berpikir Tingkat Tinggi tersebut diperoleh informasi bahwa nilai $\mathrm{F}$ hitung sebesar 4,739 dengan nilai 0,035 atau kurang dari 0,05 , hal ini memberikan makna bahwa pembelajaran PBM berpengaruh terhadap berpikir tingkat tinggi siswa. Selanjutnya seperti yang dipaparkan pada Tabel 3 rata-rata berpikir tingkat tinggi juga menunjukkan bahwa rata-rata kelas yang menerapkan PBM lebih tinggi dari kelas kontrol yaitu 78,208. 
Dari hasil penelitian menunjukkan bahwa pembelajaran biologi dengan menggunakan model Pembelajaran Berdasarkan Masalah (PBM) pada konsep Jenis Limbah dan Daur Ulang Limbah yang diterapkan di kelas eksperimen dapat meningkatkan keterampilan berpikir tingkat tinggi siswa secara signifikan. Ini dapat dilihat dari hasil tes keterampilan berpikir tingkat tinggi siswa setelah diberikan pembelajaran dengan model Pembelajaran Berdasarkan Masalah (PBM). Hal ini terbukti pada pengujian hipotesis dengan menggunakan program SPSS versi 17 for windows, dengan membandingkan nilai $\mathrm{t}$ hitung dengan $\mathrm{t}$ tabel, kemudian diperoleh nilai t hitung $>\mathrm{t}$ tabel.

Pada kelas eksperimen diterapkan model Pembelajaran Berdasarkan Masalah (PBM) dan model pembelajaran ini juga ternyata mampu meningkatkan keefektifan pembelajaran sehingga dapat meningkatkan keterampilan berpikir tinggi siswa. Hal ini sejalan dengan hasil penelitian Yulinda (2011) yang menunjukkan bahwa model Pembelajaran Berdasarkan Masalah (PBM) dapat meningkatkan keterampilan berpikir tingkat tinggi siswa pada pelajaran biologi. Ini juga didukung oleh hasil penelitian Hasting (2001); Wang et al (1998); Duch et al (2002) menemukan Pembelajaran Berdasarkan Masalah (PBM) dapat mengembangkan keterampilan berpikir kritis dan analitis serta menghadapkan siswa pada latihan untuk memecahkan masalah dalam kehidupan nyata. Morgan (1995) menemukan pembelajaran di sekolah adalah melatih keterampilan berpikir siswa sehingga membuat siswa menjadi cerdas.

Rindell (1999) menerapkan model PBL dalam pembelajaran, menemukan terjadinya pelibatan mental yang cukup tinggi dan terjadi interaksi yang baik antara siswa dan guru sehingga kemampuan berpikir kritis siswa meningkat. Lawson (2000) menemukan pembelajaran pada pelajaran kimia, fisika, biologi, dan geologi dengan pendekatan hipotetico-deduktivereasoning dapat melatih keterampilan berpikir siswa. Hurst (1996); Dult (1997); Marinick (2001) semuanya menemukan bahwa pembelajaran yang melibatkan kegiatan analisis masalah, penyusunan hipotesis, manipulasi variabel, mendesain dan melaksanakan penyelidikan, melakukan prediksi, dan menginterpretasi hasil penyelidikan dapat mengembangkan kemampuan berpikir analitis dan logis pada siswa.

Sebelum pembelajaran dilaksanakan dengan menggunakan model Pembelajaran Berdasarkan Masalah (PBM), proses belajar mengajar di kelas didominasi oleh guru. Sehingga siswa tidak aktif dalam kegiatan pembelajaran. Akan tetapi setelah dilakukan kegiatan dengan menggunakan model Pembelajaran Berdasarkan Masalah (PBM) siswa terlihat lebih aktif, selain itu guru juga tidak lagi mendominasi kelas, siswa dibiarkan belajar secara mandiri. Indikator keterampilan berpikir tingkat tinggi yang digunakan dalam penelitian ini ada 6 indikator yaitu: merumusan masalah (mengajukan pertanyaan), merumuskan hipotesis, merancang percobaan atau pengamatan, mengumpulkan data, menganalisis data dan merumuskan kesimpulan.

Pada kelas eksperimen, setelah dilaksanakan pembelajaran dengan model Pembelajaran Berdasarkan Masalah (PBM) diperoleh hasil rata-rata ketercapaian indikator berpikir tingkat tinggi daripada hasil rata-rata ketercapaian berpikir tingkat tinggi sebelum digunakan model Pembelajaran Berdasarkan Masalah (PBM). Hal ini menunjukkan bahwa adanya peningkatan ketercapaian indikator keterampilan berpikir tingkat tinggi yang diperoleh siswa. Semua indikator keterampilan berpikir tingkat tinggi mengalami peningkatan.

Pendekatan problem solving memiliki kecenderungan inkuiri sebagai proses yang aktual untuk mendapatkan pengetahuan. Ketika para guru menggunakan pendekatan problem solving di depan kelas, diharapkan agar siswa terlibat dalam berpikir analisis, sintesis, dan 
evaluasi. Proses berpikir seperti ini tergolong kemampuan berpikir tinggi (Blosser, 1988). Beberapa ide di benak siswa yang diperoleh dari kegiatan pembelajaran semuanya didasarkan pada keyakinan bahwa belajar terdiri dari makna yang dibangun siswa (Hein, 1996).

Selama proses pembelajaran berlangsung pada penelitian ini ada tujuh belas indikator yang dikembangkan berdasarkan lima tahapan model Pembelajaran Berdasarkan Masalah yaitu, tahap pertama meliputi: siswa memahami tujuan pembelajaran, siswa menunjukkan minat dan motivasi terhadap masalah yang disajikan, siswa memahami masalah yang disajikan. Tahap kedua meliputi: mulai menuliskan tugas-tugas belajar yang berhubungan dengan masalah-masalah yang disajiakan, merencanakan pemecahan masalah secara bersama-sama dalam kelompok. Tahap ketiga meliputi: mengumpulkan informasi dari berbagai sumber persiapan pemecahan masalah, melakukan penyelidikan dalam upaya pemecahan masalah, saling bertukar informasi untuk memecahkan masalah dengan teman dalam kelompok, memberikan kontribusi ide pemecahan masalah, mendengarkan pendapat orang lain dalam diskusi kelompok, mengikuti instruksi yang diberkan di lembar kerja siswa dalam pemecahan masalahnya, mengumpulkan tugas (laporan penyelidikan) dengan baik dan tepat waktu. Tahap keempat meliputi: menyajikan laporan tersebut dalam diskusi kelas, secara aktif melibatkan dirinya dalam diskusi kelas. Tahap kelima meliputi: melakukan analisis dan evaluasi terhadap hasil kerja kelompoknya dalam pemecahan masalah, membandingkan hasil kerja pemecahan masalahnya dengan pemecahan masalah yang diinformasikan guru atau pemecahan masalah yang dilakukan kelompok lain, menyimpulkan hasil pembelajaran berdasarkan pada hasil penyelidikan yang dilakukan oleh semua kelompok.

\section{KESIMPULAN}

1. Pembelajaran menggunakan model PBM berpengaruh positif terhadap hasil belajar siswa, ini dapat dilihat dari rata-rata hasil belajar kelas kontrol 73,475 dan pada kelas perlakuan sebesar 82,917 dan dilihat dari nilai $\mathrm{F}$ hitung $=4,157$ sedangkan $\mathrm{F}$ tabel $=$ 0,05 artinya $\mathrm{F}$ hitung $>\mathrm{F}$ tabel.

2. Pembelajaran menggunakan model PBM berpengaruh positif terhadap keterampilan berpikir tingkat tinggi siswa, ini dapat dilihat dari rata-rata nilai keterampilan berpikir tingkat tinggi kelas kontrol 65 dan kelas perlakuan 78,208 dan dilihat dari nilai $\mathrm{F}$ hitung $=4,739$ sedangkan $\mathrm{F}$ tabel $=$ 0,05 artinya $F$ hitung $>F$ tabel.

\section{DAFTAR PUSTAKA}

Ayatusa'adah. 2013. Pengembangan Perangkat Pembelajaran Model Addie pada Konsep Daur Ulang Sampah terhadap Hasil Belajar dan Keterampilan Berpikir Tingkat Tinggi di SMA. Tesis Tidak diterbitkan. Banjarmasin: Program Pascasarjana Universitas Lambung Mangkurat Arends, R. I. 2008. Learning To Teaching. Yogyakarta: Pustaka Pelajar.

Arikunto, S. 2010. Prosedur Penelitian Suatu Pendekatan Praktek. Jakarta: Rineka Cipta.

Blosser, P. E. 1988. Teaching Problem Solving-Secondary School Science. ERIC/SMEAC Science Education Digest No. 2, 1988.

BNSP. 2006. Petunjuk Teknis Pengembangan Silabus dan Contoh/Model Silabus SMA/MA Mata Pelajaran Biologi. Jakarta: Departmen Pendididkan.

Brookhart, Susan M. How to Asses Higherorder Thinking Skills in Your Classroom. Alexandria: ASCD. 2010.

Depdag RI. 2006. Undang-Undang dan Peraturan Pemerintah RI tentang Pendidikan. Jakarta: Depag RI.

Duch, B. J., Allen, D. E. \&. White, H. B. 2002. Problem-Based Learning: 
Preparing Students to Succeed in the $21^{\text {st }}$ Century. (Online) http://www. pondnetwork.org. Diakses 5 September 2014.

Hastings, D. 2001. Case Study: ProblemBased Learning and the active Classroom. (Online). http:/www. cstudies.ubc.ca/facdev/services/newsl etter/index/html. Diakses 6 Septeber 2014.

Hein, G. E. 1996. Constructivist Learning Theory. The Museum and the Needs of People. Jerusalem, Israel; CECA (International Committee of Museum Educators) Conference 15-22 October 1996.

Herman, T. 2007. Pembelajaran Berbasis Masalah untuk Meningkatkan Kemampuan Berpikir Matematis Tingkat Tinggi Siswa Sekolah Menengah Pertama. Jurnal Pendidikan, No.1. Januari 2007.

Hurst, R. W. 1996. Facilitating Successful Prediction Problem Solving in Biology through Application of Skill Theory. Journal of Research in Science Teaching. 33(5): 541-552.

Kemendikbud. 2013. Pedoman Pelatihan Implementasi Kurikulum 2013. Jakarta: Badan Pengembangan SDM Dikbud dan Mutu Pendidikan.

Koohang, A., Riley, L. \& Smith, T. 2009. E-Learning and Constructivism: From Theory to Appl. Interdisciplinary Journa of E-Learning and Learning Objects, 5: 2009.

Kwartolo, Y. 2012. Multiple Intelligences \& Implemenasinya dalam Taksonomi Bloom. Jurnal Pendidikan Penabur, 11(18).

Lewly, dkk. 2009. Pengembangan Soal untuk Mengukur Kemampuan Berpikir Tingkat Tinggi Pokok Bahasan Barisan dan Deret Bilangan di Kelas IX Akselerasi SMP Xaverius Maria Palembang. Jurnal Pendidikan Matematika, 3(2).

Lawson, A. E. 2000. The Generality of Hypotetico - Deductive Reasonin: Making Scientific Thinking Explicit.
The American Biology Teacher, 62(7): 482-495.

Mendikbud. 2013. Peraturan Menteri Pendidikan dan Kebudayaan Nasional No. 54 Tahun 2013 Tentang Standar Kompetensi Lulusan Untuk Satuan Pendidikan Dasar dan Menengah. Jakarta: Depdikbud.

Mendikbud. 2013. Peraturan Menteri Pendidikan dan Kebudayaan Nasional No. 65 Tahun 2013 Tentang Proses Untuk Satuan Pendidikan Dasar dan Menengah. Jakarta: Depdikbud.

Morgan, W. R. 1995. "Critical Thinking"What Does That Mean? Journal College Science Teacher (JCST). 24(5): 336-340.

Nur, M. \& Wikandari, P. R. 2000. Pengajaran Berpusat kepada Siswa dan Pendekatan Konstruktivis dalam Pengajaran. Surabaya: Pusat Studi Matematika dan IPA Sekolah. Universitas Negeri Surabaya.

Nur, M. 2011. Model Pembelajaran Berdasarkan Masalah. Surabaya: Universitas Negeri Surabaya.

Rindell, A. J. A. 1999. Applying InquiryBased and Cooperative Group Learning Strategies to Promote Critical Thinking. Journal of College Science Teaching (JCST) 28(3): 203207.

Rofiah, E., Nonoh, S. A., \& Elvin, Y. E. 2013. Penyusunan Instrumen Tes Kemampuan Berpikir Tingkat Tinggi Fisika pada Siswa SMP. Jurnal Pendidikan Fisika, No.2. September 2013.

Suprijono, A. 2010. Cooperative Learning. Yogyakarta: Pustaka Pelajar.

Tuncer. 2006. Jonassen's Constructivist Principles. (Online). http://construc tivisteducation.blogspot.com/2006/04 /jonassens-constructivist-principles. html diakses 17 April 2014.

Wang, H. C. A; Thomson; \& Shuler, C. F. 1998. Essential Components of Problem-Based Learning for the K-12 Inquiry Science Instruction. (Online). 
http://searchyahoo.com/search?p=pro blem+based+learning. Diakses 5 September 2014.

Yulinda, R. 2011. Hasil Belajar, Kinerja, dan Keterampilan Berpikir Tingkat Tinggi Siswa SMA pada Pembelajaran Konsep Jenis dan Daur Ulang Limbah melalui Proses-Proses Problem Solving. Tesis Tidak Dipublikasikan. Banjarmasin: Pascasarjana Pendidikan Biologi.
Yamin, M. \& Maisah. 2012. Orientasi Baru Ilmu Pendidikan. Jakarta: Referensi.

Zannah, F. 2012. Hasil belajar, kinerja, dan keterampilan berpikir tingkat tinggi siswa SMA pada pembelajaran konsep protista melalui pendekatan inkuiri terbimbing. Tesis tidak dipublikasikan. Banjarmasin: Pascasarjana Pendidikan Biologi. 